\title{
DISTRIBUTION OF TWO SEMELFACTIVES IN RUSSIAN: -NU- AND -ANU-
}

\author{
JULIA KUZNETSOVA AND ANASTASIA MAKAROVA \\ University of Tromsø
}

ABSTRACT

Russian semelfactive verbs formed with the suffix -nu- are well-known in the literature (Isachenko 1960; Maslov 1948, 1965; Zaliznjak \& Šmelev 2000). However, the distribution between two semelfactive suffixes - nu- and -anuis less studied. Makarova \& Janda $(2009,90)$ suggest that "there is no clear trend concerning the frequency of -nu- vs. -anu-", so the nature of the distribution between the two semelfactive suffixes remains unresolved. In this paper we explore 2041 semelfactive verbs from the Russian National Corpus ( $\mathrm{RNC}^{1}$ ) produced with the two suffixes and show that: 1) distribution of the two suffixes partly depends on the number of the syllables in the base, 2) suffix -anu- is more recent and most monosyllabic roots are currently undergoing a shift from - nu- to - anu-, and 3) prefixed verbs most frequently choose the -nu- semelfactive suffix, because the pairing of a prefix and a root functions as multisyllabic base. These principles function as tendencies and we do not postulate a clear-cut division. This paper is written within the theoretical framework of Cognitive Linguistics, which allows us to fully capture the complex distribution of the two suffixes.

\section{[1] INTRODUCTION}

\section{[1.1] Background}

The general consensus in the linguistic literature (Vinogradov 1938; Bondarko 1971; Townsend 1975; Švedova et al. 1980; Zaliznjak \& Šmelev 2000) is that verbs with non-disappearing - $\mathrm{nu}$ - can denote semelfactive situations. Semelfactive is a type of Aktionsarten which refers to "one "quantum" of activity, described by the base verb" (Zaliznjak \& Šmelev 2000,118), where a base verb denotes a series of multiple uniform actions, e.g. the base verb stučat' 'knock' and its semelfactive derivative stuknut' 'knock once'. Such verbs often refer to simple physical actions, acoustic or optical phenomena (Zaliznjak \& Šmelev 2000, 118), e.g. prygnut' 'jump', kriknut' 'shout once', sverknut' 'flash once'.

The -nu- suffixation model is very productive, especially for spontaneous and highly colloquial speech, and many such $n u$-verbs are expressive (Švedova et al.

[1] www.ruscorpora.ru

[2] «один «квант» деятельности, описываемой исходным глаголом» (Translation ours - JK, АM). 
1980). Zelenin $(2007,99-100)$ points out that a large number of semelfactives in -nu- appeared in Russian during and soon after the 1917 Revolution. Zelenin emphasizes that this could be connected not only to the expressiveness of -nu-, but also to the high overall dynamism of that period in the Russian history. Even more expressivity is associated with a modification of the -nu- suffix, namely -anu-, e.g. stučat ' 'knock' - stuknut' 'knock once' - stukanut' 'knock once with force' (Švedova et al. 1980, § 840; Townsend 1975, 105).

Recent articles have shown that the -nu-/-anu-distribution is more complex and expressivity is not the only factor. Plungjan $(2000,218)$ points out that there are several ${ }^{3}$ morphemes with identical meaning and that their distribution is complementary depending on verbal stems, but admits that sometimes the distribution is free. There are verbs that allow the formation of both types of semelfactives (around 50\% according to the database referred to in Dickey \& Janda (2009) and Makarova \& Janda (2009)), while others only allow one of the two suffixes. Moreover, even in cases where both forms (with -nu- and with -anu-) are attested, the choice of affix has consequences for further derivation. The -nu- suffix allows further derivation, while -anu- blocks such derivation, cf. xlebat'-xlebnut'otxlebnut', xlebat'-xlebanut'-*otxlebanut' 'slurp' (Makarova \& Janda 2009). In this article we explore the factors that govern the distribution of the two semelfactive suffixes and their derivational capacities.

\section{[1.2] -anu-vs. - $a$ - plus -nu-}

There is some controversy as to what should be recognized as the suffix -anu-. The problem concerns semelfactives produced from base verbs that belong to the -aj- morphological subclass, such as kašljanut' 'cough'. These verbs already contain - $a$ - as a part of their stem, so the -anu- sequence can be described either as the suffix -anu- or as the suffix - nu- added to a stem with a final $-a-(j$ is truncated by $-n u-)$. The second approach is taken by Švedova et al. (1980, § 836), who do not find it reasonable to analyze these examples as containing the -anusuffix. Švedova et al. choose between - $n u$ - and -anu- semelfactive suffixes using presence/absence of expressivity as a decisive factor. The expressive verbs are recognized as having the -anu- suffix, while non-expressive have the -nu- suffix.

For the purposes of this paper we always analyze a sequence -anu-as the suffix -anu-, we believe that synchronically it is reasonable to analyze all semelfactives including [anu] as having the -anu- suffix, and not - $a$ - as a stem-final vowel and $-n u-$ as a semelfactive formant, because other stem-final vowels never combine with the -nu- suffix. We never attest forms like *grešinut' 'sin once', *krutinut' 'turn once', *svistenut' 'whistle once' with -inu-, -enu- or other suffixes, although the base verbs grešit' 'sin', krutit' 'turn', and svistet' 'whistle' have stem-final vowels.

[3] In addition to -nu- and -anu-, his list contains several circumfixes consisting of a prefix and the suffix $-n u-$, such as the pro-...-nu- circumfix that appears in prostirnut ' 'wash clothes once'. 
In other words, stems of other morphological classes show that a stem-final vowel is always truncated before -nu-, so it is only natural to assume that the stem-final $-a$ - shows the same behavior. This article explores the synchronic distribution of the -nu-and-anu- suffixes, and the origin of -anu-is beyond the scope of the present study.

\section{[1.3] Morphological and semantic classes of the verbs}

The morphological and semantic classes of a base verb play an important role in the distribution of the semelfactive affixes. For the first time this correlation was explicitly stated and statistically proven in the paper by Dickey \& Janda (2009), who analyze the distribution of two types of semelfactives, those produced with the suffix $-n u^{-}{ }^{4}$ and the prefix s-, e.g. krjaknut' 'quack once', $s$ "jazvit' 'be sarcastic once'. Dickey \& Janda (2009) argue that these two perfectivizing affixes are not randomly distributed, and their distribution is governed by two factors: the morphological class of the base verb and its semantic class. They show that the distribution is close to complementary.

The same two factors are explored in the experimental research by Makarova (2009) for the -nu- and -anu- semelfactive suffixes. Her experiment obtained semelfactives from informants for real and non-existing (nonce) Russian verbs. The total number of forms with -nu- and -anu-, along with the semantic class of the base verb is presented in Table 1 on the following page. Semantic tagging follows the RNC assignment of semantic classes ${ }^{5}$.

As we see in the Table 1, the total number of anu-forms produced by the informants is relatively high, although formations with -nu- are three times as frequent. We also see in Table 1 that the various verb classes behave differently. Only morphological classes - $a j,-{ }^{*} \check{e}^{-},-i-,-$ ova- allow $a n u$-forms, and they are quite rare for the -i-class. No anu-forms are registered for *-ěj- stems at all.

The informants strongly preferred -anu- when forming semelfactives from the ova-class. For - aj- class the informants produced both - nu- and anu-semelfactives, but for only one of the nonce verbs the number of anu-forms was notably higher than the number of $n u$-forms. For other verb classes the informants produced $n u$-semelfactives almost exclusively. Makarova $(2009,73)$ offers several possible explanations for the observed distribution. The first explanation is phonotactic: for verbs ending in -ova- and -aj- adding the - anu- suffix seems logical and natural, because the verbal stem already contains the $/ a /$ vowel $^{6}$. The other possible

[4] Dickey \& Janda (2009) do not make a distinction between - $n u$ - and -anu- semelfactives.

[5] Where the meaning of a nonce verb cannot be unambiguously identified from the context there are either several options or a question mark.

[6] One could argue that for such verbs it is illegitimate to posit the -anu- suffix, because it is hard to draw a boundary between the semelfactive suffix and the stem suffixes. The high number of -nu-forms for the same verbs, however, speaks in favor of the legitimacy of the -anu-analysis. This means that the informants in the experiment had a choice. 


\begin{tabular}{|c|c|c|c|c|}
\hline stem & verb & -anu- & $-n u-$ & semantic class \\
\hline \multirow[t]{7}{*}{$-a j-$} & trjadát' & 5 & 36 & $?$ \\
\hline & lavkát' & 8 & 48 & $?$ \\
\hline & bópat' & 1 & 42 & impact \\
\hline & gezát' & 33 & 26 & impact \\
\hline & mljatát' & 7 & 43 & impact \\
\hline & tlikát' & 0 & 61 & sound \\
\hline & gljasát' & 2 & 28 & impact \\
\hline \multirow[t]{6}{*}{$*_{-} \check{e}_{-}$} & bisét' & 3 & 9 & $?$ \\
\hline & mídet' & 4 & 31 & $?$ \\
\hline & fidét' & 6 & 14 & sound/speech \\
\hline & tipét' & 4 & 16 & $\mathrm{impact/move}$ \\
\hline & škapét' & 1 & 11 & behav \\
\hline & brjadét' & 0 & 12 & impact \\
\hline \multirow[t]{6}{*}{$-i-$} & djubít' & 1 & 12 & speech/behav \\
\hline & gazít' & 3 & 24 & behav \\
\hline & lutít' & 2 & 3 & move/possess \\
\hline & losít' & 0 & 6 & move \\
\hline & grádit' & 2 & 15 & impact/speech \\
\hline & drépit' & 1 & 6 & impact \\
\hline \multirow[t]{6}{*}{-ova- } & bazovát' & 24 & 20 & impact/sound/speec \\
\hline & biktovát' & 30 & 13 & impact \\
\hline & tintovát' & 39 & 8 & impact \\
\hline & limovát' & 5 & 4 & impact \\
\hline & mylovát' & 4 & 14 & impact \\
\hline & devnovát' & 3 & 43 & impact/sound \\
\hline \multirow[t]{4}{*}{ *-ěj- } & talét' & 0 & 11 & move \\
\hline & plasnét' & 0 & 12 & move \\
\hline & tirét' & 0 & 2 & physiol \\
\hline & dorét' & 0 & 8 & speech/behav \\
\hline Total & & 188 & 578 & \\
\hline
\end{tabular}

TABLE 1: Number of forms with -nu- and -anu-, obtained from the informants. 
factor that has an impact on the appearance of -anu- is the context the verb was used in, and semantic class of the verb. The highest percentage of -anu-forms is obtained for the verbs of the impact semantic class (note that most of the verbs in the -ova- and -aj-morphological classes, unlike other classes, belong to the semantic class impact), and additionally some of them are used in an expressive context containing phrases like tak sil'no 'so much', neožidanno rezko i gromko 'unexpectedly abruptly and loudly', izo vsex sil 'with all one's strength'. These two factors (membership in a semantic class and expressive context) are not easily separable, since in all test items they were presented concurrently.

Thus, we see that the morphological and semantic classes of the verb are important factors in the distribution of various types of the semelfactive verbs in Russian. In this study we show that these two factors are not the only ones that affect the distribution of -nu- and -anu-. On the contrary other factors are more powerful in predicting which of the two suffixes produces a semelfactive from a given base verb.

\section{[2] ANALYSIS}

This section is structured as follows. First, we present the data collected for this study. Then we discuss the distribution of semelfactive suffixes produced from unprefixed base verbs. We show that the distribution is restricted by the number of syllables in the base and the structure of the coda for the monosyllabic bases [2.2]. We also demonstrate that doublets - pairs of semelfactives produced using both suffixes $-n u$ - and -anu- from the same verbal root - have a diachronically skewed distribution [2.3]. Finally, we discuss the distribution of prefixed stems [2.4].

\section{[2.1] The data}

Our research aims at finding explanations for the distribution of the two affixes. We created a database containing 2041 semelfactives culled from the RNC. This sampling represents all examples of semelfactives in -nu- or -anu-attested in the RNC. All previous research only dealt with smaller databases. The database described in Dickey \& Janda (2009) has 296 verbs culled from Švedova et al. (1980), Zaliznjak (1980) and the "Exploring Emptiness" database developed at the University of Troms $\varnothing^{7}$. The database compiled for Makarova \& Janda (2009) contained only $322 \mathrm{nu}$-semelfactives. The RNC allowed us to find not only most of the semelfactives listed in Švedova et al. (1980), Zaliznjak (1980), but also many others, including recent occasional formations and neologisms such as snikersnut' 'eat a "Snickers". Not only is the RNC the source for the database, but it is also a tool

[7] emptyprefixes.uit.no 
for our further research on the diachronic distribution of the semelfactives (see below in section [2.3]) . $^{8}$

of the 2041 semelfactives attested in the RNC 1876 use -nu- and 165 use anuforms: 66 bases form semelfactives with both -nu- and -anu-, 99 verbs form semelfactives with -anu- exclusively, and 1810 verbs form semelfactives with - nuexclusively.

\section{[2.2] Phonological distribution}

Multi- vs. monosyllabic base

The semelfactive suffixes - $n u$ - and -anu- show a split driven by the phonological characteristics of the base, which we can state as:

THE SYLLABIC RULE: A multisyllabic base has a preference for the -nusemelfactive suffix, while a monosyllabic base tends to use the -anusemelfactive suffix.

Generally number of syllables is an important factor in the distribution of allomorphs across languages. English deadjectival verbs produced from color terms reveal the importance of this parameter: monosyllabic adjectives form verbs by adding -en (whiten, redden, blacken), while the multisyllabic adjectives cannot form verbs by adding -en (*yellowen, *orangen), see (Halle 1973; Michaels 1977). There are also opposite cases attested: in Norwegian, for instance, the formation of plural neuter nouns is dependent on the number of syllables in the base. Monosyllabic stems can receive a zero affix, while multisyllabic receive the regular -er affix, see barn (SG) - barn(PL) 'child', and prosjekt(SG) - prosjekter(PL) 'project' (for more details see Faarlund et al. (1997, 160-173)). Multi- vs. monosyllabicity is also a factor in the distribution of the Dutch diminutives, where the choice between -kje and -etje suffixes depends on the number of syllables in the base (Souman \& Gillis 2007, 186).

Some examples of Russian semelfactive verbs with mono- and multisyllabic bases can be seen in Table 2 on the next page. The syllabic rule takes into account the phonetic, but not orthographic form of a word, which can be indicated by the verb ppksnut' 'fully agree once' (abbreviation from podpisyvajus' pod každym slovom 'subscribe to each word'). This verb's base on the orthographic level does not contain any vowels, while at the phonetic level it contains four vowels: [pepekaesnut']. Since this verb uses the suffix -nu-, this is evidence in support of the hypothesis that the phonetic, but not orthographic form of the word is important for the production of the semelfactive. Our database contains 156 verbs with a multisyllabic root; all of them form a semelfactive using the suffix -nu-. In

[8] We deliberately decided not to include a few verbs that are present in the dictionaries, but do not appear in the corpus, because they do not reflect actual usage. For example, the verb atuknut' 'say tally-ho' appears in Zaliznjak's dictionary, but is not attested in the corpus. 
Appendix B the reader can find a list of all verbs with multisyllabic roots found in the RNC.

\begin{tabular}{|c|c|c|c|}
\hline One syllable base & $\begin{array}{l}\text { Semelfactives } \\
\text { with suffix } \\
\text {-anu- }\end{array}$ & Two or more syllable base & $\begin{array}{l}\text { Semelfactives } \\
\text { with suffix } \\
-n u^{-}\end{array}$ \\
\hline grab- 'rob’ & grabanut' & babax- 'bang' & babaxnut' \\
\hline krut- 'turn' & krutanut' & kukarek- 'crow' & kukareknut' \\
\hline gaz- 'speed' & gazanut' & murlyk- 'purr' & murlyknut' \\
\hline psix- 'be hysterical' & psixanut' & kuvyr- 'somersault' & kuvyrnut' \\
\hline šik- 'show off' & šikanut' & xoxot- 'laugh loudly' & xoxotnut' \\
\hline dolb- 'hollow' & dolbanut' & carap- 'scratch' & carapnut' \\
\hline
\end{tabular}

TABLE 2: Examples of the phonological distribution of semelfactive suffixes.

Verbs that have recently appeared in Russian follow the syllabic rule: multisyllabic bases form semelfactives using -nu-, while monosyllabic bases form semelfactives using -anu-. Table 3 shows several verbs that recently appeared in the corpus (the year of the first appearance in the corpus is shown in the last column of the table). As we see, monosyllabic bases xelp- 'help', faks- 'fax' and ring- 'ring-' produce semelfactives with the suffix -anu-, while multisyllabic bases snikers- 'Snickers' and tolkin- 'Tolkien' produce semelfactives with the suffix -nu-.

\begin{tabular}{lllll}
\hline semelfactive & gloss & base & suffix & year \\
\hline xelpanut' & 'help' & xelp- & -anu- & 2004 \\
faksanut' & 'fax' & faks- & -anu- & 2000 \\
ringanut' & 'ring' & ring- & -anu- & 2000 \\
snikersnut' & 'eat a "Snickers"' & snikers- & - nu- & 2000 \\
tolkinut'sja & 'go crazy and become an avid fan & tolkin- & -nu- & 1997 \\
& of J.R.R. Tolkien' & & & \\
\hline
\end{tabular}

TABLE 3: Recently produced semelfactives with their year of appearance in the RNC.

Thus, we can conclude that the choice of the semelfactive suffix depends on the number of syllables in the base. Multisyllabic bases choose the suffix -nu-; this fact can be explained by the tendency towards having fewer syllables in the resulting verb. However, monosyllabic bases occur with both suffixes -nu-and -anu-, so suffix distribution with monosyllabic bases requires further investigation. 


\section{Coda consonant cluster}

In this section we discuss the distribution of the two semelfactive suffixes with monosyllabic bases. This distribution depends on the structure of the coda of the base. We show that verbs with a one-consonant coda like nyr- 'dive' and krut'turn' have equal distributions of -nu- and -anu- (i.e. semelfactive verbs like nyrnut' 'dive once' and krutanut' 'turn once' are equally probable), while bases with two consonant clusters like pisk- 'squeak' and zvezd- 'thwack' have a preference for the -anu- suffix (i.e. semelfactives like zvezdanut' 'thwack once' occur more frequently than semelfactives like pisknut' 'squeak once'). The presence of the consonant cluster is also mentioned by Markov (1970) as a possible factor that triggers the appearance of the -anu- suffix. In this paper this hypothesis is elaborated and supported by quantitative evidence.

Table 4 on the next page presents the distribution of the -nu- and -anu- suffixes according to the type of coda in the monosyllabic base. Among the verbs with a monosyllabic base in our database there are 1324 verbs with a one-consonant coda. 1217 of these verbs produce semelfactives with the suffix - $n u$ - (this is $65 \%$ of all semelfactives with the suffix - $n u-)$ and 107 verbs produce semelfactives with the suffix-anu- (66\% of all semelfactives with the suffix-anu-). Thus we see that verbs with a one-consonant cluster coda show the same distribution between -nu- and -anu- as all semelfactive verbs in our database. The chi-square test shows that the difference is not statistically significant (chi-square $=0.01, d f=1, P=0.92)^{9}$. However, if we compare verbs with two-consonant cluster codas, we see that from the 437 such verbs in our database, 379 produce semelfactives using the suffix $-n u-$ ( $20 \%$ of all -nu-semelfactives) and 58 produce semelfactives using-anu- (36\% of all -anu-semelfactives). So the distribution of the two suffixes is notably different for verbs with two consonant cluster codas. If the distribution of 437 twoconsonant coda verbs were the same as the overall distribution, there would be $402 \mathrm{nu}$-semelfactives and $32 \mathrm{anu}$-semelfactives among them. The observed distribution is significantly different from this prediction: the chi-square test shows $P=0.03$ (chi-square $=4.76, d f=1$ ). Therefore we can conclude that the distribution of the two suffixes is governed by:

THE CONSONANT CLUSTER RULE: Having two consonants in the coda of a monosyllabic base increases the chance that the -anu- semelfactive suffix will be used.

In other words, Russian tends to break up the potential consonant clusters you get with the -nu-suffix by using the anu-variant of the semelfactive suffix. The choice of the allomorphs based on the structure of the consonant cluster is not unique for the distribution of -nu- and -anu-. Other Russian allomorphic affixes

[9] According to standard practice, we assume that the difference is significant if $P<0.05$. 


\begin{tabular}{llllll}
\hline & $\begin{array}{l}\text {-nu- } \\
\text { (number } \\
\text { of verbs) }\end{array}$ & $\begin{array}{l}\text {-anu- } \\
\text { (number } \\
\text { of verbs) }\end{array}$ & \% of -nu- & \% of -anu- & $\begin{array}{l}P \\
\text { (chi-square } \\
\text { test) }\end{array}$ \\
\hline total & 1876 & 163 & 100 & 100 & \\
(C)VC & 1217 & 107 & 65 & 66 & 0,92 \\
(C)VCC & 379 & 48 & 20 & 30 & 0,03 \\
\hline
\end{tabular}

TABLE 4: Number of monosyllabic bases with one and two consonants in the coda ${ }^{9}$.

where the choice depends on the presence and structure of the consonant cluster can be exemplified by -c-/-ec- distribution in plural forms and oblique singular forms. If a base ends in one consonant the variant $-c$ - is used, while if the base ends in two-consonant cluster the -ec- variant of the suffix is chosen: žil'-c-a 'tenantG.SG' vs. begl-ec-a 'runaway-G.SG'. The same factor is reported to influence the formation of Russian imperative: in stressed stems bases ending in one consonant are opposed to the bases ending in a consonant cluster: bros'- $\emptyset$ vs. krikn-i (see Nesset 2008, 157ff for more details).

\section{[2.3] Diachronic distribution: -nu-/-anu- doublets}

In this section we claim that the distribution of the two semelfactive suffixes with unprefixed one-syllable bases also depends on a diachronic factor. While nowadays the distribution between new semelfactives produced with - $n u$ - and -anu- is purely phonological and depends on the number of syllables, prior to the appearance of the semelfactive suffix -anu- only one semelfactive suffix existed. Therefore at that period all semelfactives regardless of the phonological structure of their base were produced using the suffix -nu-. However since the suffix -anustarted to function as a separate semelfactive affix, competition between the two affixes began. Currently we can observe the competition in the domain of onesyllable bases, where semelfactives are shifting from the suffix -nu- to the suffix -anu-. The shift from the -nu- to the -anu- semelfactive suffix can be best shown by examining the doublets - pairs of semelfactives produced from the same base with both suffixes, e.g. rubnut'-rubanut' 'chop once'. For most doublets the peak of anu-use is in the last quarter of the twentieth century. This tendency can be shown on a chart, for example Figure 1 on the following page showing the distribution of reznut' and rezanut' 'cut once'. The number of examples of each verb is summed for each 25-year period from 1775 to 1999. Note that this means that the data from the period between years 2000 and 2006 attested in the corpus is not present on the chart. Each dot of the solid line on the figure shows how many

[9] The numbers in the third and fourth rows do not add up to the numbers in the second row, because the data on all semelfactives also includes three consonant cluster codas as well as open syllables. 


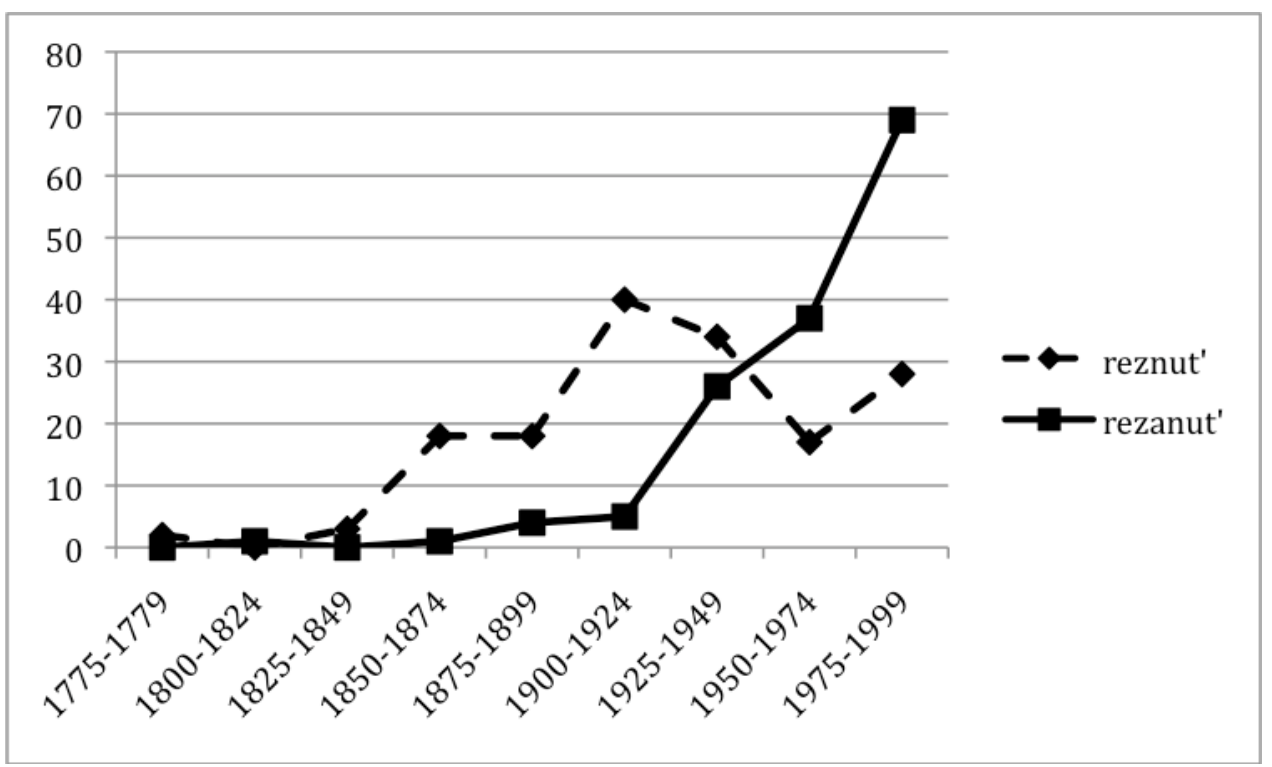

FIGURE 1: Verbs reznut' and rezanut' 'cut once': diachronic distribution (occurrences).

occurrences of the form rezanut' are found in the RNC for that period of 25 years. Each dot of the dashed line shows how many examples of reznut' are found for the same period.

Reznut' has its peak of occurrences in the first quarter of the 20th century, while rezanut' has less than 10 examples per 25 years up until 1925. However, in the second quarter of the 20th century we see a notable increase in anu-uses, while at the same time we observe a decrease of nu-uses. In the last two quarters rezanut' predominates over reznut'.

Another doublet rugnut'-ruganut' 'swear once' (see Figure 2 on the next page) also shows us that at an earlier period (1800-1849) the nu-variant was used more often. The period between 1850 and 1874 shows equal numbers of attestations of rugnut' and ruganut' in the corpus. After that ruganut' strongly predominates over rugnut'.

Thus, for two doublets: reznut'-rezanut' and rugnut'-ruganut' we see a shift from the nu-variant to the anu-variant. However for many of the verbs this method cannot be used, since the number of occurrences of one of the verbs is too low for comparison. This can be illustrated on the example of the pair pugnut'-puganut' 'scare once'. The verb pugnut' is more frequent in the corpus; it has 127 occurrences as opposed to only nineteen for puganut'. Thus we do not have enough data to compare the distribution of the - $n u$ - and anu-variants using number of occurrences for each 25-year period. For such cases we propose another method of 


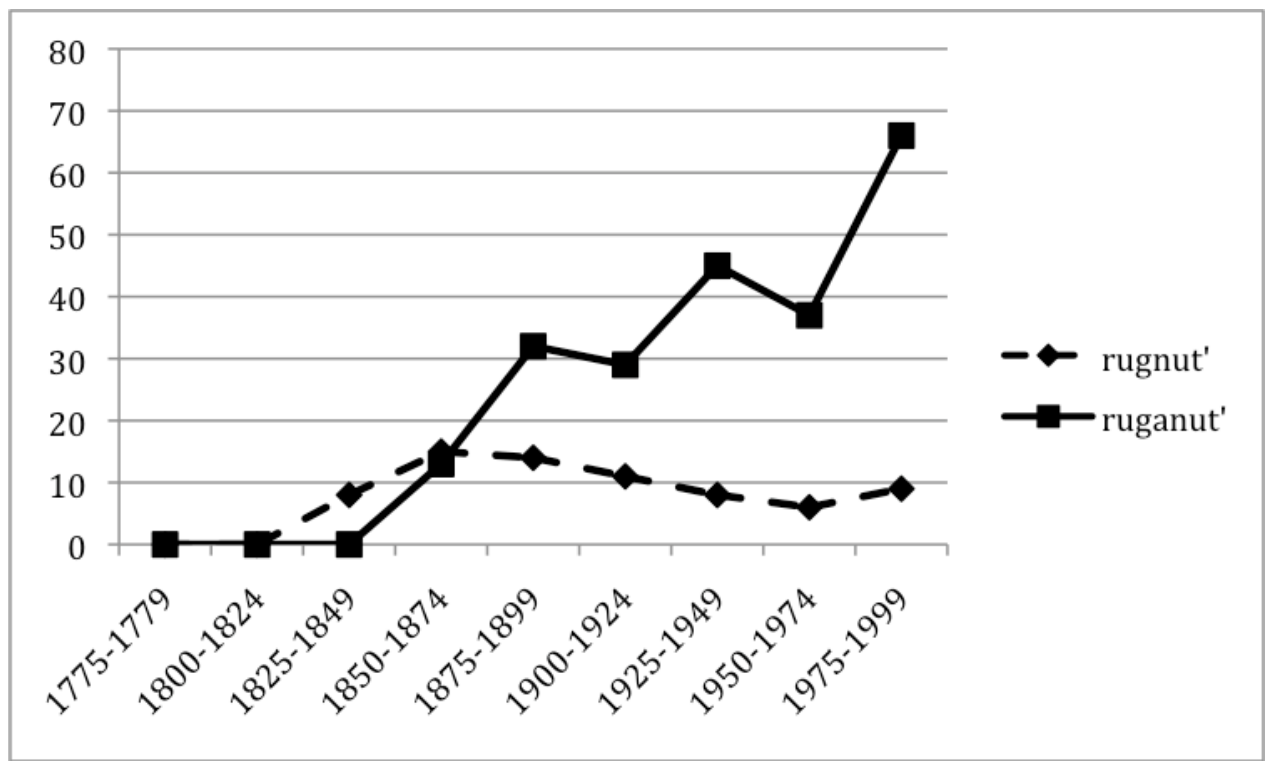

FIGURE 2: Verbs rugnut' and ruganut' 'swear once': diachronic distribution (occurrences).

comparison: we calculate the mean of the years when the examples are attested. This method allows us to study diachronic distribution even when the available data is limited. The average year shows, for instance, that most of the uses of puganut' belong to the end of the twentieth century (mean of the years is 1987), while most of the examples of pugnut' are registered significantly earlier (mean of the years is 1921). Thus although the number of occurrences is higher for the $n u$-variant, the anu-variant is more recent.

It has to be noted here that average of the years of occurrence can be used only as a relative measure, not as an absolute one. This means that we can compare the diachronic distribution of the two forms and conclude that one of them is more recent than the other. However, the number of texts for each period in the RNC is not balanced and the corpus has more data for the period between 1950 and 2006 than for the earlier periods. For these reasons the mean of years for pugnut' - year 1921 - does not really tell us when the verb pugnut' was most frequently used. It might have been used most in the 19th century, but the data in the corpus would not allow us to confirm that because there is not enough data for that period. We are more confident about the average of the years of uses of puganut' since all of them occur in the 20th century which is better exemplified in the corpus. But we can be sure that the average of the years of occurrence for pugnut' (1921) and for puganut' (1987) indicate a difference in the relative distribution of these two forms over time. 
There are all together sixty-six -nu-/-anu- doublets found in the RNC. For fiftyeight of them the average of the years for the $n u$-variant is lower than or equal to the average of the years for the anu-variant. The list of doublets and their average years of occurrence can be seen in Appendix A. Thus we can conclude that modern Russian is undergoing a shift from $n u$-semelfactives to anu-semelfactives for monosyllabic bases.

\section{[2.4] Prefixes}

Three hypotheses for prefixed semelfactives

Above we discussed the behavior of unprefixed stems. We have shown that their distribution can be mostly explained by phonological factors: monosyllabic bases tend to use the anu-semelfactive suffix, while multisyllabic bases tend to use the suffix -nu-. Now we turn to prefixed stems and observe how semelfactive suffixes are distributed with these stems.

There are 1225 prefixed verbs in our database and nearly all of these verbs use the semelfactive suffix -nu-. There are only three exceptions - where a verb that contains a prefix uses the semelfactive suffix -anu-. All three such verbs contain the prefix s-. These verbs are: $s$-šib-anu-t' 'knock down', $s$-blev-anu-t' 'throw up once', and s-ygr-anu-t 'play once ${ }^{10}$. Therefore we can say that with the exception of these three verbs the distribution of the two suffixes is determined by:

THE PREFIX RULE: Prefixed bases choose the semelfactive suffix -nu-.

Sixteen out of nineteen verbal prefixes contain a vowel. Only the prefixes $s^{-}, v-$ and $v z$ - do not contain a vowel. This suggests that the behavior of prefixed bases is not that different from the behavior of unprefixed bases. If a prefix contains a vowel, it automatically transforms a prefixed base into a multisyllabic base, which as we know always uses the semelfactive suffix -nu-. Thus the behavior of prefixed bases with prefixes containing a vowel follows from the distribution of monosyllabic vs. multisyllabic bases. We only have to account for the bases with nonsyllabic prefixes which show the same preference for the semelfactive suffix - nuand explain why three exceptions with prefix s- are possible. We offer three hypotheses that can explain the behavior of bases with non-syllabic prefixes in the derivation of the semelfactive: these hypotheses can be called the mobile vowel hypothesis, the morphological boundary hypothesis and the analogy hypothesis. After discussing the explanatory power of each hypothesis we choose the last one: the analogy hypothesis, which allows us to discard the prefix rule, since the distribution of the suffixes - $n u-$ and -anu- with prefixed verbs is fully explained by the syllabic rule and analogy.

[10] One might argue that the verb skazanut' 'say once' that belongs to the database also contains prefix s-. However this verb has a fused root and is no longer divided into the prefix s-and the verb kaz-for the speakers of modern Russian, so it will not be discussed. 
The mobile vowel hypothesis states that in a prefix ending in a consonant there is always a mobile vowel -o-. Etymologically this vowel is derived from a yer, since the prefix $v$ - is derived from $v v^{-}, v z$ - is derived from $v z z$ - and $s$ - is derived from $s \sigma$ - (see Vasmer 1964). In modern Russian this vowel can still be seen in the alternations of prefixes in the contexts of a vowel or a consonant cluster: see such prefixed verbs as vo-jti 'come in', voz-nesti 'praise', so-edinit' 'unite'. The mobile vowel hypothesis explains the distribution of semelfactives produced from bases with non-syllabic prefixes: according to this hypothesis a prefixed stem always has two or more syllables, and therefore the distribution follows from the syllabic rule. However this hypothesis is not able to account for the exceptions with prefix $s$ - produced with the suffix -anu-. Following this hypothesis we would have to assume that any occurrence of the prefix $s$ - contains a vowel, which would mean that the base is multisyllabic and therefore has to choose the suffix -nu-.

The morphological boundary hypothesis states that morphological boundaries have effects on the phonological level. This effect can be seen for example in the consonant clusters that occur in Russian only across a morphological boundary and never within a morpheme. Such clusters as $v z l$ in $v z$-lomat' 'break open' and vzgl' in $v z$-gljanut' 'look once' occur only when prefix $v z$ - is attached to a root starting with a consonant or a consonant cluster. No other words in Russian contain such clusters. This suggests that a morphological boundary plays an important role on the phonological level, functioning not only as morphological, but also as a phonological boundary. According to the morphological boundary hypothesis the morphological boundary functions as a syllable boundary, so a prefixed verb always contains at least two syllables, and therefore distribution of the bases with non-syllabic suffix follows from the syllabic rule. This hypothesis though, like the mobile vowel hypothesis, fails to account for the exceptions with the prefix $s$ - and the semelfactive suffix -anu-. According to the morphological boundary hypothesis these words would have multisyllabic bases and therefore would use the suffix -nu-.

The analogy hypothesis states that verbs with a syllabic prefix are subject to the syllabic rule, while other prefixed verbal bases choose -nu-by analogy with more frequent syllabic prefixes. This hypothesis though accounts for the strong preference of prefixed bases for the -nu- suffix, allows some instability for the bases with non-syllabic prefixes, since analogy may not always be followed. The analogy hypothesis allows for the existence of exceptions such as sšibanut' 'knock down', sblevanut' 'throw up once', and sygranut' 'play once', though it does not explain why more exceptions to the rule are not attested. However, we are exploring a new, developing phenomenon and the RNC might be too conservative to contain new prefixed semelfactives with the -anu- suffix. If we turn to the Google search engine, we can find more anu-semelfactives produced from bases with a non-syllabic prefix. Table 5 on the following page shows examples of the verbs 


\begin{tabular}{llc}
\hline \multicolumn{1}{c}{ verb } & \multicolumn{1}{c}{ gloss } & occurrences in Google \\
\hline vpixanut' & 'push in once' & 132 \\
vlipanut' & 'get into a mess once' & 2 \\
vzletanut' & 'fly up once' & 1 \\
vzbrykanut' & 'kick up once' & 7 \\
sxlopanut' & 'collapse once' & 2 \\
stolkanut' & 'clash together once' & 2 \\
\hline
\end{tabular}

TABLE 5: Examples of the prefixed -anu-semelfactives in Google.

that along with the regular semelfactive produced using the suffix -nu-, also occasionally produce anu-variants. Thus, we can conclude that the behavior of prefixed semelfactives is best accounted for by the analogy hypothesis.

\section{[2.5] Derivational base of a prefixed semelfactive}

Prefixed verbs with a semelfactive suffix raise another interesting question: from which base are the prefixed semelfactives derived? There can be three possible origins for the derivation: the prefixed semelfactive can be produced from the base imperfective verb, the prefixed perfective verb, or the unprefixed semelfactive verb. For example, the prefixed semelfactive otxlebnut' 'take a sip' may originate from the base imperfective xlebat' 'slurp' using both the prefix ot-and the semelfactive suffix - nu- at the same time, it can be derived from the prefixed perfective otxlebat' 'slurp a part' by adding the semelfactive suffix or it can be produced from the unprefixed semelfactive xlebnut' 'slurp once' by prefixation. Different semelfactives show evidence for different types of derivational bases. First, for the prefixed semelfactive vzgljanut' 'look once' there exist the unprefixed semelfactive gljanut' and the base imperfective gljadet' 'see', but there is no prefixed perfective *vzgljadet'. Thus vzgljanut' shows us that prefixed semelfactives cannot be derived from the prefixed perfective verb. Second, for the prefixed semelfactive svergnut' 'overthrow' there exists only the prefixed perfective verb svergat', and there is no unprefixed semelfactive *vergnut' or imperfective base verb *vergat'. Thus, svergnut' shows that a prefixed semelfactive cannot be produced from the unprefixed semelfactive and cannot be produced from a base imperfective verb. Third, for the prefixed semelfactives vzdremnut' 'take a nap' and vsplaknut' 'have a little cry' there exist neither prefixed perfective ('vzdremat', *vsplakat') nor unprefixed semelfactive (*dremnut', *plaknut'), so such prefixed semelfactives can only be produced by circumfixation of a prefix together with a semelfactive suffix. We can see that from the three possible derivational bases for the prefixed semelfactive none of the forms can function as a derivational base for all prefixed semelfactives. While we can propose that some verbs are produced via deriva- 
tion (either through the unprefixed semelfactive: gljadet'>gljanut'>vzglajnut' 'look once' or through prefixed perfective: svergat>svergnut' 'overthrow'), for the semelfactives like vzdremnut' 'take a nap' and vsplaknut' 'have a little cry' we have to conclude that the prefixed semelfactive functions as a morphological construction ${ }^{11}$ prefix-V-nu-t' produced from a verbal root $\mathrm{V}$ and a verbal prefix using the verbs like otxlebnut 'take a sip' and vzgljanut 'look once' as model even though neither the prefixed verb, nor the unprefixed semelfactive exists in Russian.

Summing up, we can conclude that the four elements mentioned above - the prefixed semelfactive, the base imperfective verb, the prefixed perfective verb, and the unprefixed semelfactive form a family of related morphologic constructions. These families differ in the size: some contain all four possible members, while some have only the base imperfective verb and the prefixed semelfactive.

\section{[3] CONCLUSIONS}

We formulated two rules that govern the distribution of the two Russian semelfactive suffixes: the syllabic rule and the consonant cluster rule. We have shown that the distribution of -nu-and-anu- suffixes is driven by phonological factors. A crucial factor for the distribution is the number of the syllables of the base. Multisyllabic bases use the semelfactive suffix -nu-, while monosyllabic bases tend to use the suffix -anu-. An additional factor in the distribution of the semelfactives produced from a monosyllabic base is the structure of the coda. Monosyllabic bases with a coda consonant cluster more frequently use the semelfactive suffix -anu-. Currently monosyllabic bases are undergoing a shift from the -nu- to the -anu- semelfactive suffix. This can be seen both from the behavior of new verbs in the RNC and from -nu-/-anu- doublets (pairs of semelfactive verbs produced from the same root with two different semelfactive suffixes). For most doublets the $a n u$-variant is more recent than the nu-variant. Most prefixed verb bases use the semelfactive suffix -nu-, which for syllabic prefixes can be explained as a result of a syllabic rule, while for non-syllabic prefixes is best explained by analogy. Some prefixes form a circumfix together with the suffix -nu-, which signifies that prefix$V$-nu-functions as a morphological construction, and is derived neither from the unprefixed semelfactive, nor from the prefixed perfective.

Our paper shows that the same factors govern synchronic and diachronic distribution. While the syllabic rule and the consonant rule are tendencies discernible on the synchronic level, the doublet semelfactives also show that diachronic change is governed by the same tendencies.

The rules formulated in this paper should be regarded as strong trends rather than absolute principles. These trends can be observed as statistical tendencies. Our findings are in agreement with Cognitive Linguistics where linguistic phe-

[11] We use the term "construction" as it is done within the theory of Construction Grammar (see Fillmore 1988; Goldberg 1995, 2006; Tomasello 2003; Fried \& Boas 2005) 
nomena are recognized as gradient rather than defined according to clear-cut boundaries (Ross 1972; Lakoff 1973; Langacker 1986, 2008). We conclude that the proposed analysis accounts best for variation among the two Russian semelfactive suffixes and allows us to capture the diachronic shift from -nu- to -anu-.

\section{REFERENCES}

Bondarko, A.V. 1971. Vid i vremja russkogo glagola. Moscow: Prosveščenie.

Dickey, S.M. \& L.A. Janda. 2009. Xoxotnul, sxitril: The relationship between semelfactives fromed with -nu- and s- in Russian. Russian Linguistics 33(3). 229-248.

Faarlund, J.T., S. Lie \& K.I. Vannebo. 1997. Norsk referansegrammatikk. Oslo: Universitetsforlaget.

Fillmore, Ch.J. 1988. The mechanisms of 'Construction Grammar'. In S. Axmaker, A. Jaisser \& H. Singmaster (eds.), Proceedings of the Fourteenth Annual Meeting of the Berkeley Linguistics Society., 35-55. Berkeley: Berkeley Linguistics Society.

Fried, M. \& H.C. Boas. 2005. Grammatical Constructions: Back to the Roots, vol. 4. Amsterdam/Philadelphia: John Benjamins.

Goldberg, A.E. 1995. Constructions. A Construction Grammar Approach to Argument Structure. Chicago, IL: University of Chicago Press.

Goldberg, A.E. 2006. Constructions at Work: the nature of generalization in language. Oxford: Oxford University Press.

Halle, M. 1973. Prolegomena to a theory of word formation. Linguistic Inquiry 4. 3-16.

Isachenko, A.V. 1960. Grammatičeskij stroj russkogo jazyka v sopostavlenii s slovackim. Bratislava: Izdatel'stvo Slovatskoi Akademii nauk.

Lakoff, G. 1973. Fuzzy grammar and the performance/competence terminology game. In C. Corum, T.C. Smith-Stark \& A. Weiser (eds.), Papers from the 9th Meeting of the Chicago Linguistic Society, Chicago.

Langacker, R. 1986. An Introduction to Cognitive Grammar. Cognitive Science 10(1). $1-40$.

Langacker, R. 2008. Cognitive Grammar. A Basic Introduction. New York: Oxford University Press.

Makarova, A. 2009. Psycholinguistics evidence for allomorphy in Russian Semelfactives. University of Troms $\varnothing$, unpublished MA thesis. Available at: http://www .ub . uit.no/munin/handle/10037/2377. 
Makarova, A. \& L.A. Janda. 2009. Do It Once: A Case Study of the Russian -nuSemelfactives. Scando-Slavica 55. 78-99.

Markov, V.M. 1970. Problema formirovanija samostojatel'nyx morfem na osnove protivopostavlenija fonetičeskix variantov. In Voprosy grammatičeskogo stroja russkogo jazyka, 3-20. Kazan': Izdatel'stvo Kazanskogo Universiteta.

Maslov, Ju.S. 1948. Vid i leksičeskoe značenie glagola v russkom jazyke. Izvestija Akademii Nauk SSSR: Otdelenie literatury i jazyka 7(4). 303-316.

Maslov, Ju.S. 1965. Sistema osnovnyx ponjatij i terminov slavjanskoj aspektologii. Voprosy obščego jazykoznanija 53-80.

Michaels, D. 1977. Linguistic Relativity and Colour Terminology. Language and speech 20. 333-343.

Nesset, T. 2008. Abstract Phonology in a Concrete Model. Cognitive Linguistics and the Morphology-Phonology Interface. Foreign Language Study. Berlin and New York: Mouton de Gruyter.

Plungjan, V.A. 2000. 'BYSTRO' v grammatike russkogo i drugix jazykov. In Slovo $v$ tekste i slovare: Sb. st. $k$ 70-letiju akademika Ju.D. Apresjana, 212-223. Moscow: Jazyki russkoj kul'tury.

Ross, J.R. 1972. The category squish: Endstation hauptwort. In P.M. Peranteau, J.N. Levi \& G.C. Phares (eds.), Papers from the 8th Meeting of the Chicago Linguistic Society, 316-338. Chicago.

Souman, A. \& S. Gillis. 2007. A longitudinal study of acqusition of diminutives in Dutch. In I. Savickeene \& W. Dressler (eds.), The Acquisition of Diminutives. A cross-linguistic perspective, 183-206. Amsterdam-Philadelphia: John Benjamins.

Tomasello, M. 2003. Constructing a language: a usage based theory of language acquisition. Cambridge: Harvard University Press.

Townsend, C.E. 1975. Russian Word-formation. Bloomington: Slavica Publishers, Inc.

Vasmer, M. 1964. Ètimologičeskij slovar' russkogo jazyka. Moscow: Progress.

Vinogradov, V.V. 1938. Sovremennyj russkij jazyk. Grammatičeskoe učenie o slove. Moscow: Učpedgiz.

Švedova, N.Ju. et al. 1980. Russkaja grammatika vol. I. Moscow: Akademija nauk SSSR. 
Zaliznjak, A.A. 1980. Grammatičeskij slovar' russkogo jazyka. Moscow: Russkij jazyk.

Zaliznjak, A.A. \& A.D. Šmelev. 2000. Vvedenie v russkuju aspektologiju. Moscow: Jazyki russkoj kul'tury.

Zelenin, A.V. 2007. Jazyk russkoj emigrantskoj pressy (1919-1939). Saint Petersburg: Zlatoust.

APPENDICES

A LiST OF ALL NU/ANU DOUBLETS FROM THE RNC (66 VERBS)

\begin{tabular}{lllrrrr}
\hline & Doublet & Gloss & \multicolumn{2}{c}{$\begin{array}{c}\text { Frequency } \\
\text {-nu- }\end{array}$} & -anu- & \multicolumn{2}{c}{$\begin{array}{c}\text { Average year } \\
\text {-nu- }\end{array}$} \\
\hline boltnut' & boltanut' & shake, dangle & 20 & 4 & 1931 & 1982 \\
gasnut' & gasanut' & fade & 695 & 1 & 1954 & 1956 \\
glotnut' & glotanut' & swallow & 544 & 1 & 1973 & 1992 \\
grebnut' & grebanut' & row, rake & 582 & 6 & 1941 & 1943 \\
groxnut' & groxanut' & bang, kill & 703 & 6 & 1978 & 1990 \\
gryznut' & gryzanut' & gnaw & 19 & 2 & 1963 & 2002 \\
davnut' & davanut' & crush, & 128 & 23 & 1952 & 1962 \\
& & press down & & & & \\
dernut' & deranut' & tug, drink a shot & 2575 & 5 & 1951 & 1982 \\
erznut' & erzanut' & fidget & 10 & 1 & 1952 & 1999 \\
ževnut' & ževanut' & chew & 3 & 1 & 1953 & 1997 \\
katnut' & katanut' & roll & 27 & 8 & 1936 & 1989 \\
kliknut' & klikanut' & call & 550 & 1 & 1905 & 2002 \\
krutnut' & krutanut' & twist, turn & 65 & 148 & 1968 & 1991 \\
krutnut'sja & krutanut'sja & twist, turn (refl.) & 40 & 58 & 1976 & 1995 \\
listnut' & listanut' & turn the page & 8 & 3 & 1964 & 1991 \\
lupnut' & lupanut' & hit & 3 & 16 & 1952 & 1982 \\
maznut' & mazanut' & smear & 124 & 8 & 1964 & 1971 \\
maxnut' & maxanut' & wave & 5989 & 26 & 1950 & 1987 \\
\hline Continued & on & & & &
\end{tabular}

Continued on next page

[12] In this table the verbs are grouped in three sets. First, verbs for which the anu-variant has a higher average year than the $n u$-variant ( 56 verbs). Second, verbs for which the average years for the anu-variant and the $n u$-variant are equal (2 verbs). Third, verbs for which the $a n u$-variant has a lower average year than the $n u$-variant (8 verbs). Within each set the verbs are given in Russian alphabetical order. 


\begin{tabular}{|c|c|c|c|c|c|c|}
\hline \multirow[b]{2}{*}{- nu- } & Doublet & \multirow[t]{2}{*}{ Gloss } & \multicolumn{2}{|c|}{ Frequency } & \multicolumn{2}{|c|}{ Average year } \\
\hline & -anu- & & $-n u-$ & -anu- & $-n u-$ & -anu- \\
\hline motnut' & motanut' & $\begin{array}{l}\text { reel, wind, waste } \\
\text { money }\end{array}$ & 713 & 24 & 1952 & 1975 \\
\hline pisnut' & pisanut' & write, pee & 9 & 4 & 1948 & 1979 \\
\hline pugnut' & puganut' & frighten & 127 & 19 & 1921 & 1987 \\
\hline reznut' & rezanut' & cut & 177 & 198 & 1933 & 1976 \\
\hline rubnut' & rubanut' & chop & 18 & 176 & 1921 & 1978 \\
\hline rugnut' & ruganut' & swear at & 83 & 273 & 1921 & 1954 \\
\hline rugnut'sja & ruganut'sja & swear at & 87 & 2 & 1979 & 1981 \\
\hline sblevnut' & sblevanut' & throw up & 2 & 3 & 1970 & 2000 \\
\hline sverknut' & sverkanut' & twinkle & 1579 & 5 & 1941 & 1993 \\
\hline skaknut' & skakanut' & gallop & 121 & 2 & 1957 & 2003 \\
\hline skrebnut' & skrebanut' & scrape & 11 & 3 & 1914 & 1998 \\
\hline sopnut' & sopanut' & wheeze & 13 & 1 & 1946 & 1987 \\
\hline stegnut' & steganut' & whip & 111 & 40 & 1935 & 1952 \\
\hline streknut' & strekanut' & jump, escape & 8 & 7 & 1910 & 1954 \\
\hline strugnut' & struganut' & plane, shave & 1 & 1 & 1929 & 2000 \\
\hline stuknut' & stukanut' & knock & 2501 & 11 & 1953 & 1994 \\
\hline sypnut' & sypanut' & pour & 16 & 81 & 1907 & 1981 \\
\hline tolknut' & tolkanut' & push & 3239 & 24 & 1950 & 1961 \\
\hline truxnut' & truxanut' & dread & 9 & 3 & 1889 & 1975 \\
\hline trjaxnut' & trjaxanut' & shake, jolt & 1286 & 22 & 1945 & 1988 \\
\hline xapnut' & xapanut' & grab & 92 & 2 & 1978 & 1982 \\
\hline xvastnut' & xvastanut' & boast & 12 & 5 & 1916 & 1962 \\
\hline xvatnut' & xvatanut' & snatch & 6 & 68 & 1964 & 1992 \\
\hline xvostnut' & xvostanut' & give a lash & 4 & 1 & 1983 & 2004 \\
\hline xlebnut' & xlebanut' & slurp & 606 & 5 & 1956 & 1974 \\
\hline xlestnut' & xlestanut' & lash & 368 & 20 & 1945 & 1991 \\
\hline xlestnut'sja & xlestanut'sja & lash (refl.) & 2 & 3 & 1916 & 1987 \\
\hline xlystnut' & xlystanut' & whip & 4 & 1 & 1862 & 1997 \\
\hline xrapnut' & xrapanut' & snore & 17 & 2 & 1904 & 1966 \\
\hline capnut' & capanut' & seize & 152 & 1 & 1967 & 2000 \\
\hline čerknut' & čerkanut' & scribble & 177 & 20 & 1937 & 1980 \\
\hline čerpnut' & čerpanut' & ladle out & 45 & 10 & 1930 & 1988 \\
\hline čirknut' & čirkanut' & strike & 386 & 3 & 1969 & 1984 \\
\hline šiknut' & šikanut' & hiss, show off & 66 & 7 & 1958 & 1994 \\
\hline širknut' & širkanut' & shuffle & 10 & 1 & 1966 & 1997 \\
\hline
\end{tabular}

Continued on next page 


\begin{tabular}{|c|c|c|c|c|c|c|}
\hline \multicolumn{2}{|c|}{ Doublet } & \multirow[t]{2}{*}{ Gloss } & \multicolumn{2}{|c|}{ Frequency } & \multicolumn{2}{|c|}{ Average year } \\
\hline -nu- & -anu- & & - nu- & -anu- & - nu- & -anu- \\
\hline šmygnut' & šmyganut' & slip & 460 & 3 & 1956 & 1976 \\
\hline šugnut' & šuganut' & scare off & 11 & 70 & 1930 & 1975 \\
\hline ščipnut' & ščipanut' & pinch & 61 & 2 & 1917 & 1983 \\
\hline dristnut' & dristanut' & chicken out & 1 & 1 & 1998 & 1998 \\
\hline tusnut' & tusanut' & go out & 2 & 1 & 2000 & 2000 \\
\hline dubnut' & dubanut' & freeze, kill & 1 & 4 & 2000 & 1972 \\
\hline ebnut' & ebanut' & hit & 18 & 4 & 2001 & 1975 \\
\hline ebnut'sja & ebanut'sja & hit (refl.), fall & 1 & 7 & 2002 & 2001 \\
\hline kopnut' & kopanut' & dig & 191 & 7 & 1963 & 1903 \\
\hline kusnut' & kusanut' & bite & 98 & 5 & 1968 & 1925 \\
\hline polosnut' & polosanut' & slash & 274 & 4 & 1968 & 1959 \\
\hline strignut' & striganut' & cut & 2 & 8 & 1993 & 1974 \\
\hline ščelknut' & ščelkanut' & click, flick & 1857 & 2 & 1962 & 1929 \\
\hline
\end{tabular}

B LIST OF ALL SEMELFACTIVES PRODUCED FROM UNPREFIXED MULTISYLLABIC BASES IN THE RNC (156 VERBS $)^{13}$

agaknut' 'say aha once', aguknut'sja 'have an effect', aleknut' 'say hello once', ataknut 'attack', auknut' 'halloo to each other', auknut'sja 'halloo to each other (refl.)', babaxnut' 'bang', babaxnut'sja 'bang once (refl.)', barternut' 'to barter', bašljanut' 'pay a lot', berlyknut' 'produce a sound usual for a turkey', bibiknut' 'honk', bormotnut' 'mumble', bubuxnut' 'let fall with a thud', bultyxnut' 'plunge / plop into the water', bultyxnut'sja 'plunge / plop into the water (refl.)', veernut' 'wave one's hand like a fan', vertuxnut'sja 'capsize', vizažnut'sja 'visit a visagiste', voroxnut' 'stir up', voroxnut'sja 'stir up (refl.)', voskliknut' 'exclaim', voskresnut' 'rise from the dead', voskriknut' 'exclaim', vostorgnut'sja 'admire', gagaknut' 'say “gaga", gigiknut' 'chuckle', gogotnut' 'cackle', golosnut' 'vote, hitch', gromyxnut' 'rumble', groxotnut' 'thunder', guguknut' 'drone', gygyknut' 'say "gygy", dembel'nut'sja 'return from the army', derjabnut' 'drink a shot', drebeznut' 'tinkle', drobolyznut' 'drink', duduknut' 'blow', zemljanut' 'expel from thieves', kašljanut' 'cough', kajuknu'sja 'come to an end', klokotnut' 'boil, bubble', kovyl'nut' 'hobble', kovyrnut' 'rummage', kovyrnut'sja 'fall', kozyrnut' 'show off', kolebnut'sja 'swing', kolonut' 'prick', kolupnut' 'pick', kolyxnut' 'sway', kolyxnut'sja 'sway (refl.)', kon"junkturnut' 'use the current state of affairs', kopirnut' 'copy', korotnut' 'short circuit', kritiknut' 'criticize', kuvyrknut' 'somersault', kuvyrknut'sja 'somersault (refl.)', kuvyrnut' 'somersault', kuvyrnut'sja 'somersault (refl.)', ku-

[13] The verbs are given in Russian alphabetical order. 
daxtnut' 'cackle', kudkudaknut' 'cluck', kukareknut' 'crow', kukuknut' 'cuckoo', kurlyknut' 'call (of cranes)', labuxnut'sja 'be mistaken', lepetnut' 'mumble', lobyznut' 'give a kiss', lopotnut' 'mutter', lopuxnut'sja 'drop a clanger', loxonut'sja 'drop a clanger', maternut' 'curse', maternut'sja 'curse', matjugnut' 'curse', matjugnut'sja 'curse', matjuknut' 'curse', matjuknut'sja 'curse', memeknut' 'mumble', murlyknut' 'purr', mjauknut' 'mew', nizvergnut' 'overthrow', nizvergnut'sja 'overthrow (refl.)', nizrinut' 'throw down', nizrinut'sja 'precipitate', nisprovergnut' 'subvert', piliknut' 'strum', preminut' 'to fail + to inf', rabotnut' 'work', reagnut' 'react', reanimnut'sja 'resuscitate', regotnut' 'shout', rerixnut'sja 'go crazy, study Rerikh', rokotnut' 'roar', samovydvinut'sja 'nominate oneself', skazanut' 'say something inappropriate', skal'pel'nut' 'cut with a scalpel', skrežetnut' 'grind', snikersnut' 'eat a snickers', sortirnut' 'sort', spekul'nut' 'speculate', spotyknut'sja 'stumble', stimul'nut' 'stimulate', stopornut' 'stop', strekotnut' 'chirr', stukotnut' 'knock', suetnut'sja 'fuss', sjusjuknut' 'lisp', tararaxnut' 'bang, hit', terebnut' 'finger, bother', tetexnut'sja 'hit against', tililiknut' 'make high sounds', tolkinut'sja 'go crazy and become an avid fan of J.R.R. Tolkien', tormoznut' 'stop', tormoznut'sja 'stop (refl.)', trepetnut' 'tremble', trepyxnut' 'flutter', trepyxnut'sja 'flutter (refl.)', užasnut' 'scare', užasnut'sja 'get scared', uxmyl'nut'sja 'grin', fraernut'sja 'cheat', frezernut' 'cut, mill', fujaknut' 'hit', xeraknut' 'hit', xexeknut' 'chuckle', xixiknut' 'chuckle', xlobystnut' 'hit', xolonut' 'get colder', xoxotnut' 'guffaw', xujaknut' 'hit', capcarapnut'sja 'scratch', carapnut' 'scratch', citatnut' 'quote', čelomknut' 'give a kiss', čertyxnut'sja 'swear', čiriknut' 'chirp', čifirnut' 'drink strong tea', šabarknut' 'scratch, claw', šandaraxnut' 'bang, wham', šandaraxnut'sja 'bang, wham (refl)', šandoraxnut' 'bang, wham', šararaxnut' 'bang', šaraxnut' 'hit', šaraxnut'sja 'dash aside', ševel'nut' 'move', ševel'nut'sja 'move (refl.)', šeloxnut' 'stir', šeloxnut'sja 'stir (refl.)', šoloxnut'sja 'stir (refl.)', šuxernut'sja 'take fright of', šušuknut' 'whisper', ščebetnut' 'twitter', ščegol'nut' 'flaunt', ščekotnut' 'tickle', èkspluatnut' 'exploit' 
AUTHOR CONTACT INFORMATION

Julia Kuznetsova

University of Tromsø

Teorifagbygget hus 4

TEO-H4 4.353

N-9037 Tromsø

Norway

julia.kuznetsova@uit.no

Anastasia Makarova

University of Tromsø

Teorifagbygget hus 4

TEO-H4 4.353

N-9037 Tromsø

anastasia.makarova@uit.no 